\title{
MARCADORES DISCURSIVOS EM LIBRAS
}

\author{
DISCURSIVE MARKERS IN BRAZILIAN SIGN LANGUAGE
}

\section{MARCADORES DISCURSIVOS EN LENGUA BRASILEÑA DE SEÑAS}

\author{
Lídia da Silva * \\ Thayse Goulart Strazzi **
}

\section{Resumo}

Os marcadores discursivos da Língua Brasileira de Sinais são mecanismos linguísticos utilizados na expressão sinalizada e podem ter função textual, interacional ou de acompanhamento discursivo. Com base em Risso e McNeill, estudamos esse fenômeno, utilizando os dados de uma narrativa contada por graduandos surdos (que têm a Libras como primeira língua) e ouvintes (para os quais Libras é segunda língua) do curso de licenciatura em Letras Libras. O objetivo deste trabalho é descrever os marcadores discursivos presentes na narrativa e analisar semelhanças e diferenças em relação à produção em primeira e segunda língua. Nossos resultados apontam para uso semelhante entre surdos e ouvintes, no caso de marcadores discursivos textuais e interacionais, mas no emprego de recursos mais refinados, como gestos de acompanhamento, o mecanismo está mais presente na narrativa contada por surdos.

Palavras-chave: Marcadores discursivos. Libras. Primeira e segunda língua.

\section{Introdução}

De modo geral, estudos linguísticos fazem distinção entre língua falada e língua escrita. Sobre isso não há dúvidas quando a língua em questão é produzida de forma vocal e recebida de forma auditiva em contextos de oralidade e registrada por letras e grafemas em contextos em que não se está em contato direto com o receptor da mensagem. Não é diferente no caso da Língua Brasileira de Sinais, a Libras, pois considerando que o sistema de escrita ${ }^{1}$ mais consolidado para essa língua está em expansão no território brasileiro, tem-se também

\footnotetext{
* Professora do Curso de Licenciatura em Letras Libras da Universidade Federal do Paraná (UFPR). Doutoranda do Programa de Pós Graduação em Linguística da Universidade Federal de Santa Catarina. E-mail: lidiaufpr@gmail.com

** Graduanda do Curso de Licenciatura em Letras Libras da Universidade Federal do Paraná (UFPR) participante do Projeto de Pesquisa: “Aquisição de Libras como segunda língua por ouvintes”, coordenação e orientação da primeira autora.
} 
necessidade de abordar a fala, ou seja, sua expressividade oral $^{2}$ para dela extrair conteúdos contextuais importantes, como é o caso dos marcadores discursivos.

Comecemos esclarecendo que o nosso conceito de fala corresponde à expressão sinalizada e não a considerações exclusivamente relacionadas ao aspecto "vocal" ou "oral" de sons produzidos pelo aparelho fonoarticulatório. Buscamos nos aproximar de concepções que consideram a fala como exteriorização da língua e, portanto, neste texto, como tratamos da Libras, cuja produção se dá com as mãos no espaço à frente do corpo, a fala pode relacionarse também à sinalização.

Entre os elementos visuais da comunicação em Libras, optamos por pesquisar os marcadores discursivos, a partir de estudos da língua portuguesa e de outras línguas orais, por haver um número reduzido de pesquisas sobre esse fenômeno no âmbito da língua de sinais. Ressaltamos que, à literatura teórica que sustenta esta pesquisa, soma-se nossa experiência linguística como sinalizantes, surda e ouvinte, que têm a Libras como primeira e como segunda língua.

Seguindo as definições de Risso (1996) para os marcadores discursivos, ilustramos as funções textuais baseando-nos na sinalização original, escolhida para elucidar os dados do presente estudo. Em seguida, ao tratar dos marcadores discursivos, relacionamos o espaço sub-rogado e as expressões faciais, contextualmente dadas, considerando o contínuo gestual proposto por McNeill (1992) e, após adaptá-lo para Libras, categorizamos os resultados em três diferentes grupos de gestos de acompanhamento.

Investigou-se a produção de marcadores discursivos em Libras em graduandos surdos e ouvintes durante a sinalização da história "Três machados" ${ }^{3}$, bem conhecida na comunidade surda e originalmente sinalizada por um surdo, em uma aula do curso de licenciatura em Letras Libras da Universidade Federal do Paraná. A narrativa foi, informalmente, filmada por um colega que, após gravar, também sinalizou. O corpus desta pesquisa se compõe de 10 narrativas de surdos e 10 narrativas de ouvintes. As narrativas em Libras ${ }^{4}$ foram posteriormente assistidas no Windows Media Player e a transcrição foi feita registrando os MDs no Microsoft Word, organizados em tabelas com as respectivas funções e sua posição no enunciado. Juntamente com a tabulação, houve captura de fotos extraídas dos vídeos.

Buscou-se, em seguida, verificar semelhanças e diferenças no desempenho, em primeira e em segunda língua. Para atingir esse objetivo, as seguintes perguntas de pesquisa 
foram definidas: (a) Quais as funções dos marcadores discursivos presentes na sinalização de narrativas contadas por graduandos surdos e ouvintes? (b) Quais as semelhanças e diferenças dos marcadores discursivos em Libras produzidos em primeira e em segunda língua? E, por fim, considerando que os MDs podem se manifestar em uma narrativa em Libras, foi levantada a seguinte questão: haveria alguma diferença entre a produção de pessoas surdas que adquiriram essa língua como primeira língua e de ouvintes que adquiriram como segunda língua?

Os resultados deste estudo trazem elementos que poderão contribuir para a ampliação das pesquisas na área de linguística e línguas de sinais, especialmente quanto à descrição dos marcadores discursivos, além de trazer subsídios para compreensão dos fatores envolvidos na aquisição da Libras por parte de surdos e ouvintes.

\section{Marcadores Discursivos}

Em diversas línguas, há um crescente interesse de investigação sobre o significado, a função, a forma e a posição dos Marcadores Discursivos (doravante MDs). Verifica-se, porém, tanto na literatura clássica como nas publicações mais recentes, falta de consenso quanto à definição de seu estatuto, o que, de certa forma, explica a diversidade de rótulos. Em meio a essa falta de consenso terminológico na literatura sobre o assunto, é possível encontrar, referindo-se a esses mecanismos, expressões como "marcadores conversacionais", "operadores discursivos", "marcadores de estruturação da conversação" ou "apoios do discurso". Risso (1996) diz que se tem incluído sob a rubrica de "marcadores", todos os recursos discursivos com os quais não se sabe o que fazer. A lista não se fecha nunca e não lhes é dada uma definição devida.

Consideramos, nesta pesquisa, os MDs como elementos linguísticos, lexicalizados ou não lexicalizados, variáveis e multifuncionais. Embora a classe dos MDs não disponha de critérios definidores suficientemente precisos, Penhavel (2005) observa que é possível organizá-los em dois grupos. Um está ligado mais estreitamente aos componentes ideacional e textual, o outro ao componente interpessoal do sistema linguístico, estando identificados como "funções textuais" e "funções interacionais", respectivamente.

No nível da organização do texto, Risso (1996) identifica os MDs como um conjunto de palavras ou locuções envolvidas no "amarramento" das porções de informação 
progressivamente liberadas ao longo da fala. No nível da relação interacional, o autor diz tratar-se da perspectiva assumida em relação ao assunto e à organização das relações entre os interlocutores, na estrutura interpessoal. Os MDs com função textual funcionam como mecanismos de coesão, estabelecendo algum tipo de relação semântica, às vezes quase puramente estrutural, entre diferentes unidades discursivas. De acordo com Penhavel (2005, p.1296), os MDs exercem funções textuais,

[...] quando atuam na organização do conteúdo informacional do discurso. Nesse caso, integram-se aos componentes ideacional e textual da linguagem, operando num nível hierarquicamente superior ao da sentença. Funcionam como mecanismos de coesão textual, estabelecendo algum tipo de relação semântica, e, às vezes, quase puramente estrutural, entre diferentes unidades discursivas. Propiciam, por exemplo, abertura, expansão, retomada e fechamento de tópicos e distinção de estruturas de figura e fundo. Algumas formas típicas que realizam essa função são: agora, então, e, mas, aí, ou seja, enfim, em resumo, quer dizer etc.

Encontramos exemplos de abertura, retomada e fechamento de sentenças em Libras, da narrativa "Três machados" de Rimar R. Segala e Sueli Ramalho ${ }^{5}$. Seguimos o sistema de notação por palavras para transcrição dos vocábulos de Libras para a língua portuguesa.

Figura 1 - Sinais de MD: agora, então e fim.

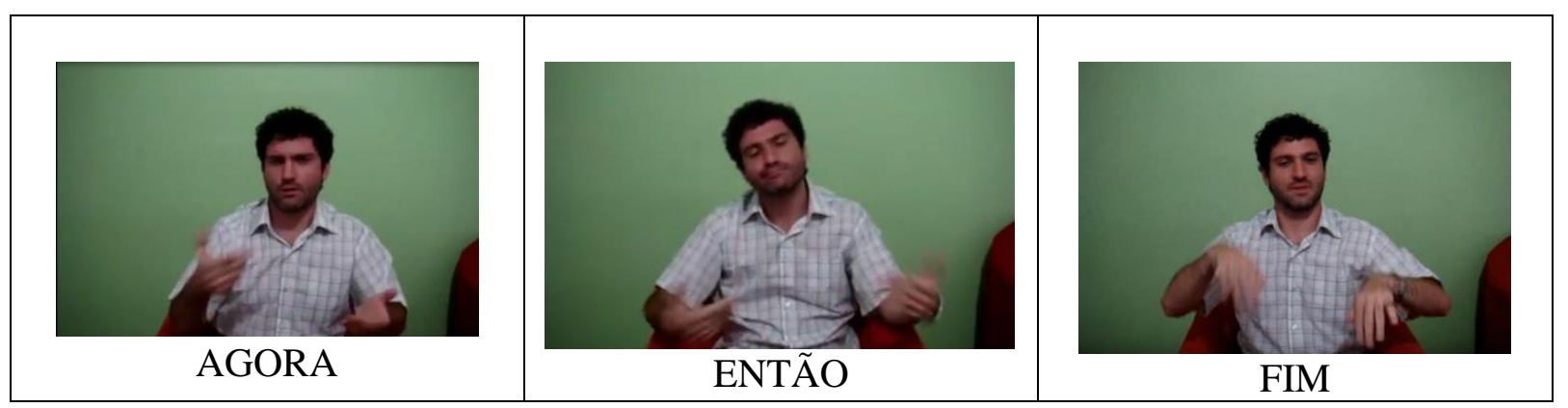

“AGORA EU FALAR HISTÓRIA TEMA TRÊS MACHADOS”; "ENTÃo, UM HOMEM APARECEU"; ACABOU, FIM DA HISTÓRIA, FIM. O termo "agora", um advérbio de tempo, é produzido em Libras com as duas mãos, palmas voltadas para cima, cujos movimentos retilíneos são produzidos de forma simultânea para dentro do espaço que ocupam. No caso da primeira sentença, o MD está abrindo o tópico do discurso. Trata-se de um sinal peculiar, que embora possa parecer desnecessário na sentença, por não se relacionar diretamente com a informatividade do texto, tem grande importância, uma vez que se caracteriza por ser o sequencializador da sinalização. 
Na expressão seguinte, o advérbio “então" é utilizado para retomar uma ideia anteriormente apresentada, sendo produzido, em Libras, com as duas mãos, palmas voltadas para baixo, que com movimento semicircular viram-se para cima. Assim como o MD anterior, sua função é textual, pois dá sequência ao texto, retomando o que foi dito anteriormente. Quanto ao MD de fechamento da terceira frase, o sinal de "fim" corresponde ao limite da sentença, à exaustão do tópico, mas nem sempre o MD de fechamento reflete a conclusão do texto, pois pode ser apenas o término de uma sequência de cenas ou ideias. No caso do exemplo destacado, além de ser duplamente colocado na sentença, o desfecho da narrativa coincide com a presença do MD.

Os MDs, como exposto anteriormente, não exercem apenas a função textual, mas cumprem também, segundo Risso (1996), papel interacional. Os MDs exercem funções interacionais quando atuam no processamento da interação conversacional, quando cumprem alguma função advinda diretamente da relação presencial entre os interlocutores, integrando, portanto, o componente interpessoal da linguagem. Os marcadores interacionais não são constituintes sentenciais, pois são exteriores ao conteúdo proposicional e sintaticamente independentes de suas unidades adjacentes.

Em português, os MDs com funções interacionais aparecem em expressões como: Entendeu? Certo? Ok? Né? Claro! Em Libras, os exemplos abaixo expressam dois MDs interacionais:

Figura 2 - Sinais de MDs: Certo? Como?

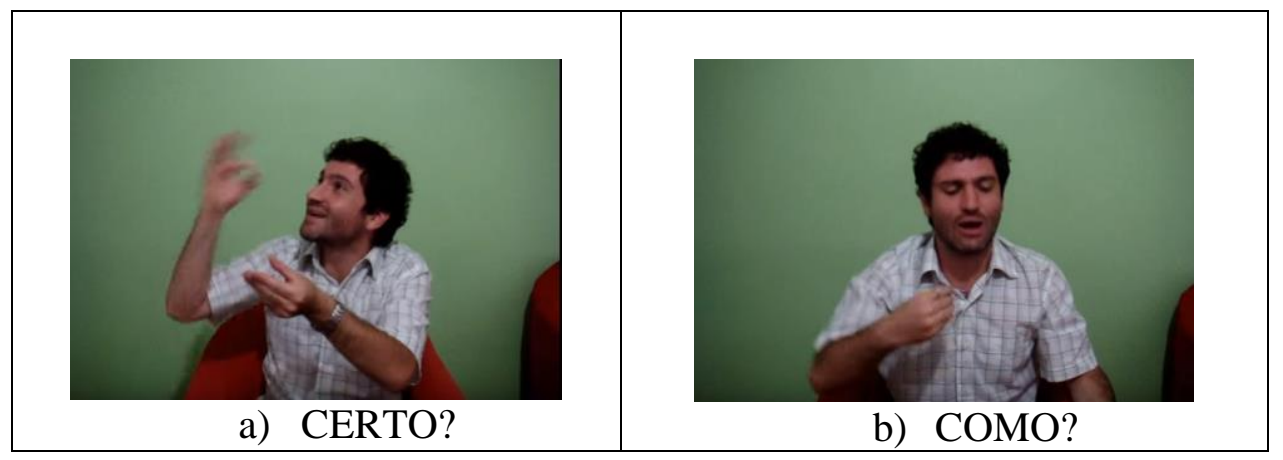

O MD “Certo?” é produzido com o dedo indicador e polegar tocando-se, enquanto os demais dedos ficam estendidos. A mão é articulada no espaço neutro à frente do corpo do sinalizante com movimentos retos para cima e para baixo. O MD "Como?" é produzido com a 
junção de todos os dedos no polegar e através da realização de movimentos retos no espaço neutro à frente do corpo. Segundo Penhavel (2005, p. 1296), uma das características dos MDs é a forte tendência para "desempenharem simultaneamente uma função textual e uma função interacional".

\section{Marcadores Discursivos na narrativa "Os três machados"}

À primeira vista pode parecer que os MDs com função textual podem ser empregados na sinalização de monólogos e que os MDs com funções interacionais só podem ser usados na interação presencial. Entretanto, não é assim que esse fenômeno se manifesta em Libras. Para tratar desse assunto faz-se necessária uma observação paralela, devido à especificidade linguística da Libras, qual seja: o uso do espaço.

Os MDs textuais aparecem normalmente na sinalização monóloga e os interacionais aparecem também na construção da narrativa. De acordo com Liddell (1995), nesse tipo de sinalização lidamos, essencialmente, com dois espaços mentais, que podem ser caracterizados como estruturas abstratas, parciais e dinâmicas, disparadas pela língua e refletidas por ela. Um desses espaços é o espaço real, o outro, é o espaço de evento.

O espaço real é decorrente da conceituação do espaço físico em que ocorre o evento da fala, o qual é, em grande medida, compartilhado pelos participantes do evento de fala. Para Liddell (1995), o espaço real é o espaço mental resultante da nossa experiência sensórioperceptual da situação corrente, incluindo participantes, objetos, contexto imediato e todo o espaço a nossa volta. Na medida em que percebemos e interagimos com o ambiente, o input sensorial é processado e compreendido com base em nossa experiência individual e cultural. O espaço real, portanto, não é uma cópia do espaço físico, embora, em grande medida, as localizações das entidades físicas correspondam às localizações em que as entidades são conceitualizadas.

O outro espaço envolvido na construção de uma narrativa em língua de sinais é o espaço do evento, resultante da conceituação do que será contado. Nesse espaço estão inseridos todos os elementos que constituem o evento, tais como: cenário, personagens, objetos, ações. É o espaço neutro à frente do corpo, onde as mãos são colocadas durante a produção dos léxicos e da gramática da língua. Ocorre, porém, que na sinalização de uma narrativa, muitas vezes, utilizamo-nos de elementos do espaço real e elementos do espaço do 
evento, tendo assim a integração de partes que constituem o espaço mental. Estas partes constituem o espaço sub-rogado (que se relaciona em alguma medida com a função interacional dos marcadores discursivos).

O espaço sub-rogado, para Liddell (1995), é o espaço resultante de integração do espaço real com um espaço do evento. Quando parte do corpo do sinalizante se torna algo ou alguém pertencente ao espaço do evento, dizemos que são criados sub-rogados. Na narrativa "Os três machados", Rimar empresta seu corpo (mãos, braços, ombros, face, olhar, tronco) para realizar o discurso direto da sereia, ela pergunta do que o lenhador precisava:

Figura 3 - Sinal de MDs: Do quê?

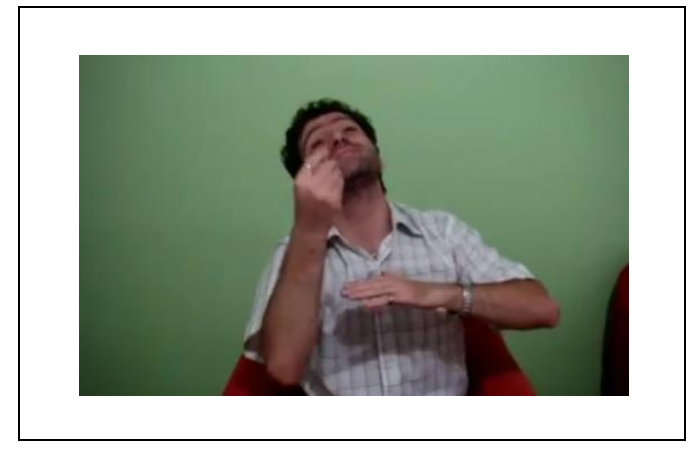

“DO QUE VOCÊ PRECISA?” A sentença foi sinalizada em momento único, tendo o sinalizante usado expressão facial como testa franzida e pescoço elevado em direção ao lenhador, pois a sentença é feita pela sereia, quando avista o lenhador na beira da lagoa preocupado e, ao mesmo tempo, usa o sinal "o quê?" em Libras, para formular sentença interrogativa complementar à expressão usada. Isso quer dizer que em Libras, os MDs interacionais aparecem em sinalização monóloga, dada a realização da incorporação de personagens, feita no corpo do sinalizante. Dessa incorporação obtêm-se as interações discursivas.

Além dos MDs com função textual e interacional outro tipo de MD, que aparece na narrativa, é bem similar aos mecanismos linguísticos colocados por McNeill (1992) como gestos. A gestualidade estaria, portanto, relacionada ao planejamento conceitual de uma mensagem a ser verbalizada. Nesse caso, o ato de mover as mãos, os braços e a cabeça durante a comunicação é entendido como gesto. McNeill (1992) afirma que os gestos são 
importantes e aprimoram a mensagem verbal, e ao referenciar o trabalho de Adam Kendon (2004), propõe o continum de Kendon, apresentado no esquema abaixo:

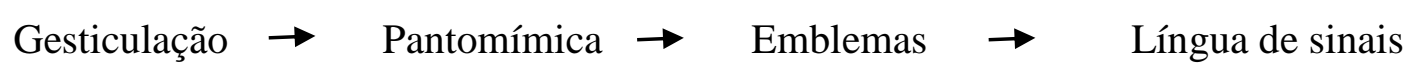

De acordo com o continum de Kendon (2004), entende-se "gesticulação" como movimento idiossincrático e espontâneo das mãos e dos braços, "pantomímica" é o gesto feito em tamanhos e proporções menores do que a corporalidade empregada na execução da gesticulação, "emblemas" são gestos convencionalizados por dada comunidade e com significado específico (acordos sociais). As "línguas de sinais", entre as quais a Libras, são sistemas linguísticos (apresentam: segmentação, composicionalidade, léxico, sintaxe, traços distintivos etc.).

Nessa tipologia, em primeiro lugar, há a representação do material linguístico (que no nosso caso chamamos de sinais lexicais dicionarizados) e em segundo, pelo material gestual (que são os movimentos espontâneos, geralmente de braços e mãos extraídos de expressões não convencionadas ou dicionarizadas). Dessa maneira, gesto e fala cooperam mutuamente para expressar os sentidos pretendidos pelos sujeitos.

Ainda em relação ao continum, faz-se importante uma revisão terminológica, uma vez que, a Libras, muitas vezes é, erroneamente, considerada uma forma de mímica. Gesser (2009) procura desfazer esse falso conceito, ao observar diferenças entre a Libras e a mímica, o tempo de produção e os parâmetros fonéticos utilizados na língua em detrimento da linguagem corporal. Da mesma forma ocorre em relação à pantomima já que, como língua, Libras não tem limitação de conteúdo e a sua iconicidade ${ }^{6}$ é uma característica, de certa forma semelhante, à iconicidade das línguas orais, como nos casos das onomatopeias. Considerando o continum de Kendon (2004), propomos que a "gesticulação" abarque todos os gestos de acompanhamento que são produzidos durante a sinalização em Libras.

Categorizamos, a partir do continum proposto por Kendon (2004), os gestos de acompanhamento nos tipos: chamamento, intervalo e consequência. Os gestos de chamamento são usados quando há a necessidade de chamar a atenção do receptor para o enunciado que virá a seguir. Traduzindo os sinais da Libras para português, teríamos exemplos do tipo: "olha", "veja", "preste atenção" "olhe para mim”. Esses gestos são feitos 
acompanhados de uma mão fechada, direcionada ao receptor e com movimentos similares a batidas leves no ombro.

Os gestos do tipo intervalo se referem ao momento em que o narrador precisar de uma interrupção temporária, mas sem finalizar o enunciado, apenas para dar uma pausa e, posteriormente, retomar o enunciado. Traduzindo os sinais da Libras para português, teríamos exemplos do tipo: "peraí", "espera" e "aguarde". Esses são feitos com a mão fechada cuja palma é virada para o receptor.

Por fim, os gestos do tipo consequência ocorrem após o acontecimento de algo que marcou o enunciado ou após alguma realização. Podem ser usados com o movimento afirmativo de cabeça feito rapidamente, indicando alguma concordância ou com movimento de mãos indicando sensação de impossibilidade de ação. Traduzindo os sinais da Libras para português, teríamos exemplos do tipo: "isso aí" "pronto", "hum" "e agora?".

O que temos percebido em relação à produção dos MDs gestuais é a otimização das expressões faciais e corporais, ou seja, as sentenças passam a ser marcadas de forma contextual e não lexicalmente (com sinais dicionarizados). Quanto ao emprego de expressões complexas, em vez das convencionadas, Finau (2004) aponta que a estrutura interna das línguas de sinais necessita do contexto sentencial para estabelecer diferentes valores de significado. Em relação a isso, Quadros, Pizzio e Rezende (2008), abordam o uso de expressões faciais como parte da comunicação humana, podendo expressar vários tipos diferentes de sentenças.

Em Libras as expressões faciais são consideradas um dos parâmetros fonológicos e estão presentes nas sentenças sinalizadas, pois dão "forma" ao enunciado. As expressões faciais podem, por exemplo, dar ênfase às sentenças através de elevações da cabeça acompanhadas de uma testa franzida, elevação das sobrancelhas, olhos mais fechados ou inclinação leve dos ombros para os lados ou para trás.

Figura 4 - Sinal do verbo ENTREGAR com sentença contextualmente marcada.

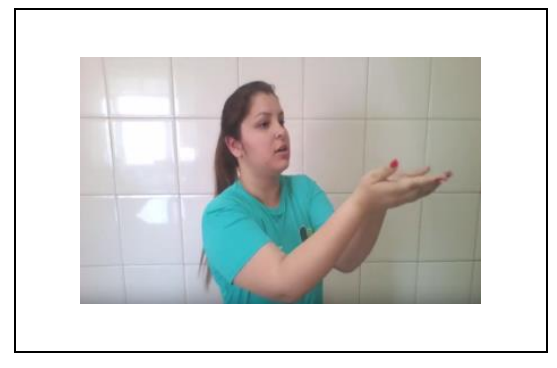

Revista Sinalizar, Goiânia, v. 2, n.2, p. 198 - 217, jul. / dez., 2017. 
Nesse caso, em vez de a sinalizante produzir cada um dos itens lexicais, equivalentes à língua portuguesa “É ESSE MACHADO QUE VOCÊ QUER?", ela opta por sinalizar o verbo ENTREGAR e realizar uma expressão facial interrogativa que através do contexto será compreendida pelo interlocutor, uma vez que seu corpo volta-se para o lenhador, com quem a sereia estava conversando. Desta forma, a sinalização completa-se com uso de apenas um item lexical, com a riqueza da expressão contextualmente marcada.

\section{Marcadores discursivos da Libras em "Os três machados": semelhanças na produção em primeira e em segunda língua}

Percebemos algumas semelhanças no emprego dos MDs com função textual, interacional e em alguns gestos de acompanhamento entre os sujeitos surdos e ouvintes.

Figura 5: MDs com função interacional.

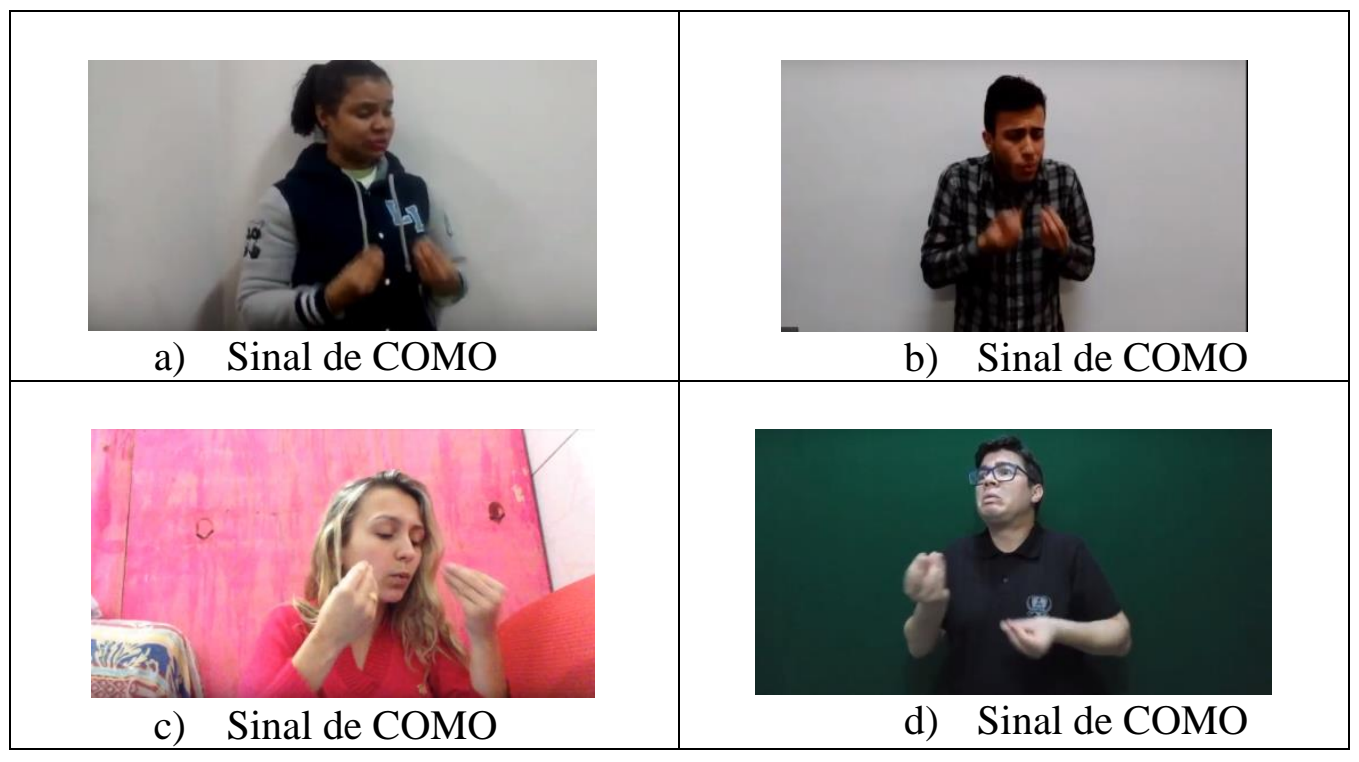

Nesses exemplos, os sinalizantes surdos (fotos "a" e "c") e ouvintes (figuras "b" e "d") emprestaram seu corpo para criação de personagens da narrativa e lhes deram voz, direcionando seus ombros para o espaço de sinalização (lócus do espaço do evento) onde o episódio ocorreu. Os quatro exemplos se referem ao contexto em que o lenhador está perguntando a si mesmo “como faço para recuperar o machado?". Nesses casos, temos os surdos e os ouvintes sinalizando "COMO" com uso de expressão facial interrogativa. 
Figura 6: MDs como gestos de acompanhamento: tipo "chamamento".

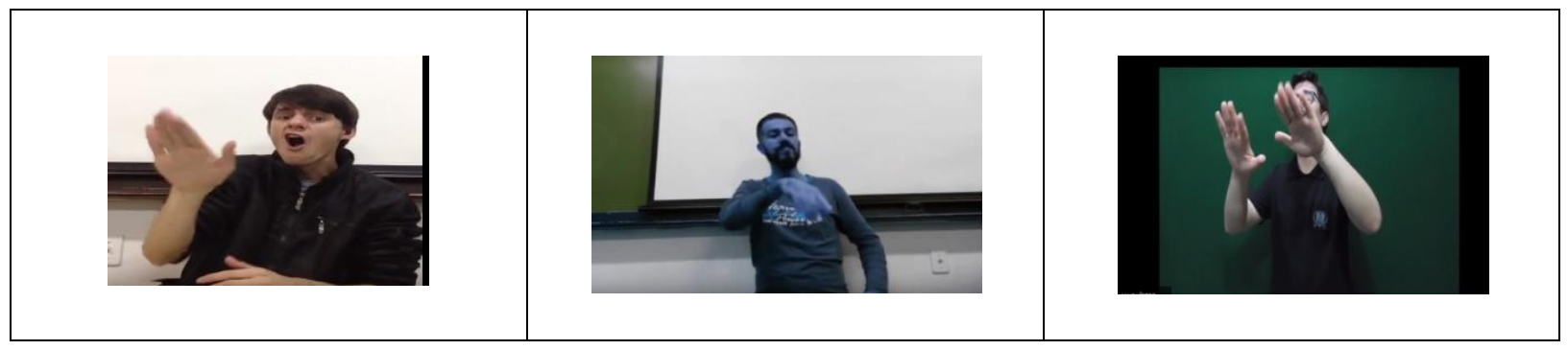

Nas duas primeiras figuras, os sinalizantes estão usando um gesto de acompanhamento que serve como chamamento. Parece que há intenção de iniciar uma conversa e por isso a bruxa balança as mãos na frente da mulher bonita para que ela a olhe. Esse gesto de acompanhamento do tipo "chamamento" é muito recorrente na comunicação em Libras e o sinalizante ouvinte, na última foto da sequência, fez uso das duas mãos para demonstrar o mesmo marcador apresentado pelos sinalizantes surdos.

Figura 7: MDs como gestos de acompanhamento do tipo "intervalo"

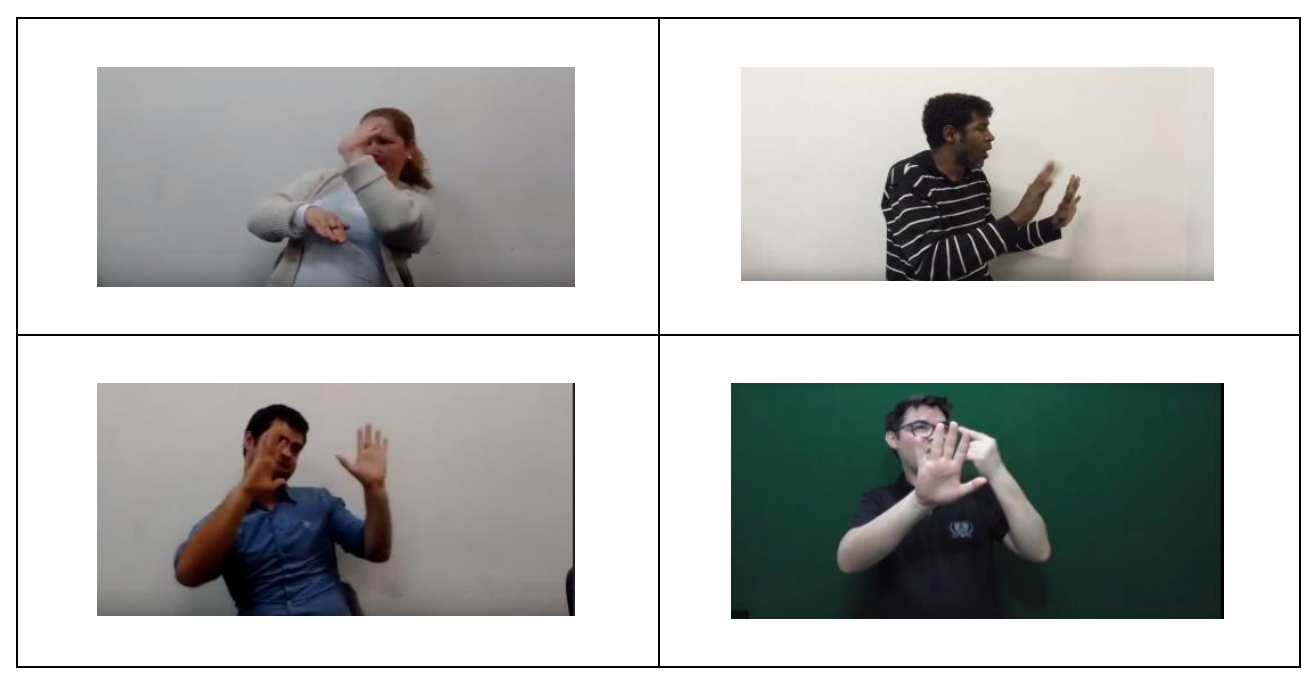

$\mathrm{Na}$ primeira foto da linha superior, a sinalizante surda usa o gesto de intervalo para indicar um pedido de espera e para isso ela usa a mão direita aberta, com a palma virada para cima, e os dedos fechados da mão esquerda. O corpo está virado para a direita no momento da sinalização, pois o pedido é feito ao personagem que estava marcado nesse lado do espaço. $\mathrm{Na}$ foto seguinte, o sinalizante surdo utiliza as duas mãos abertas com os dedos juntos e a palma virada para o receptor, com movimentos para frente e para trás, a expressão facial de pedido de espera. A sentença foi usada quando a sereia apareceu para o lenhador e, para evitar que 
ela voltasse ao fundo do lago, ele lhe pede para esperar. Na linha inferior, a primeira foto mostra o sinalizante ouvinte utilizando as duas mãos abertas com a palma virada para o receptor, indicando um pedido de espera. O seu corpo também está posicionado de acordo com a marcação dos personagens no espaço construído por ele. Na segunda foto, o sinalizante ouvinte utiliza duas mãos para produzir esse MD, ao mesmo tempo em que, com a outra mão, sinalizava o gesto de "ver" como que pedindo atenção.

Figura 8 - Sinal ESPERAR.

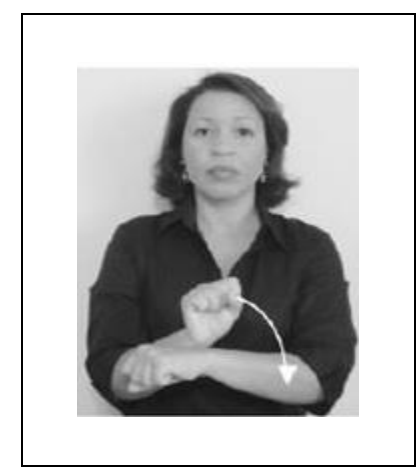

Nenhum sujeito, dentre os sinalizantes, surdo ou ouvinte, optou pelo sinal ESPERAR, ilustrado acima, que é lexical e dicionarizado.

Figura 9 - MDs como gestos de acompanhamento do tipo "consequência".

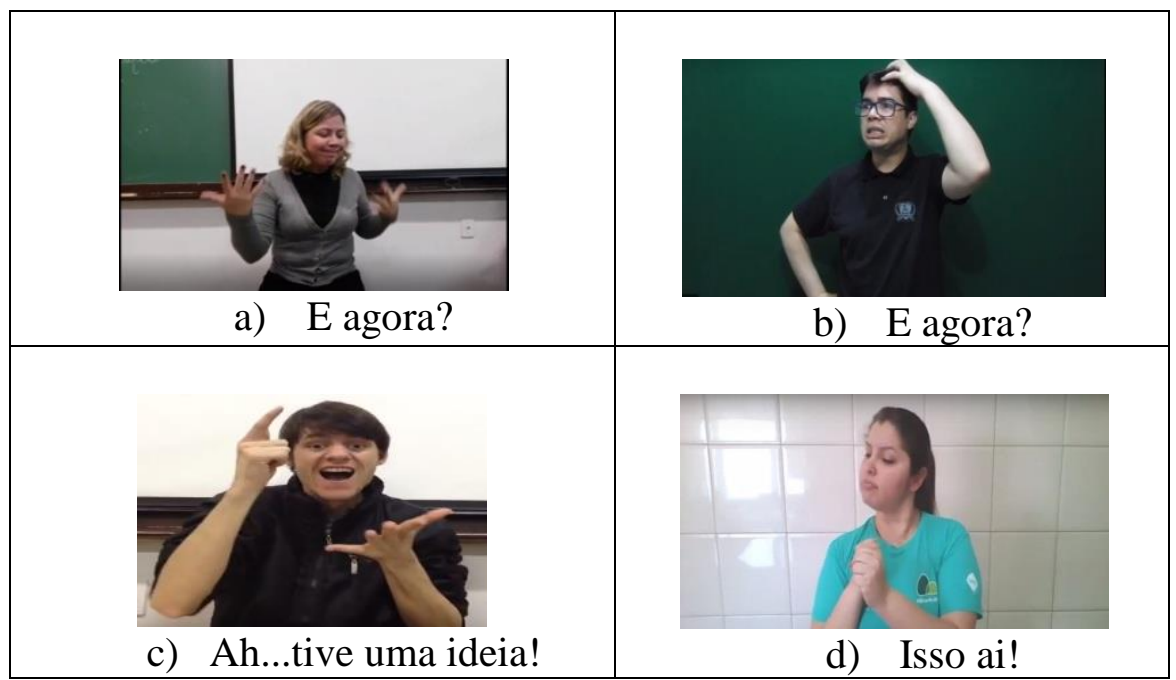

As duas imagens da linha superior, "a" e "b", referem-se ao momento em que o lenhador teve seu machado perdido na lagoa e se perguntou: "E agora?" A primeira 
sinalizante (a), que é surda, usou expressão facial como lábios fechados, contraídos, olhar direcionado para baixo, onde se encontra a lagoa, e usou as duas mãos em movimento circular, encenando um momento de indecisão e os seus ombros foram levemente virados para o lado direito, definido pela sinalizante como o espaço da lagoa. O segundo sinalizante (b) expressou a mesma intenção, só que dobrou o braço esquerdo para cima, tocando a cabeça com a mão e, para complementar, usou como expressão facial o arredondamento dos lábios, com os dentes cerrados.

$\mathrm{Na}$ primeira foto da linha seguinte, a imagem "c", representa outro MD de consequiência, que descreve o momento em que a bruxa, com inveja da mulher, teve a idéia do feitiço. O sinalizante surdo tocou a testa com o dedo indicador e, logo depois, estalou os dedos, com as sobrancelhas para cima e os lábios abertos. Outro exemplo de MD de conseqüência aparece ilustrado na foto "d", quando a sinalizante ouvinte escolhe o sinal de colocar o machado no ombro e, em seguida, faz um movimento afirmativo de cabeça com o olhar direcionado à árvore caída, para expressar o momento em que o lenhador cortou a árvore e sentiu satisfação por realizar o trabalho.

\section{Marcadores discursivos da Libras na narrativa "Os três Machados": diferenças na produção em primeira e em segunda língua}

Destacamos nesta seção dois exemplos de usos distintos de MDs para o mesmo contexto de sinalização: o momento em que o lenhador pediu à sereia para buscar o machado que caíra na lagoa e ela respondeu: “Tá bom”.

Figura 10 - MDs interacionais.

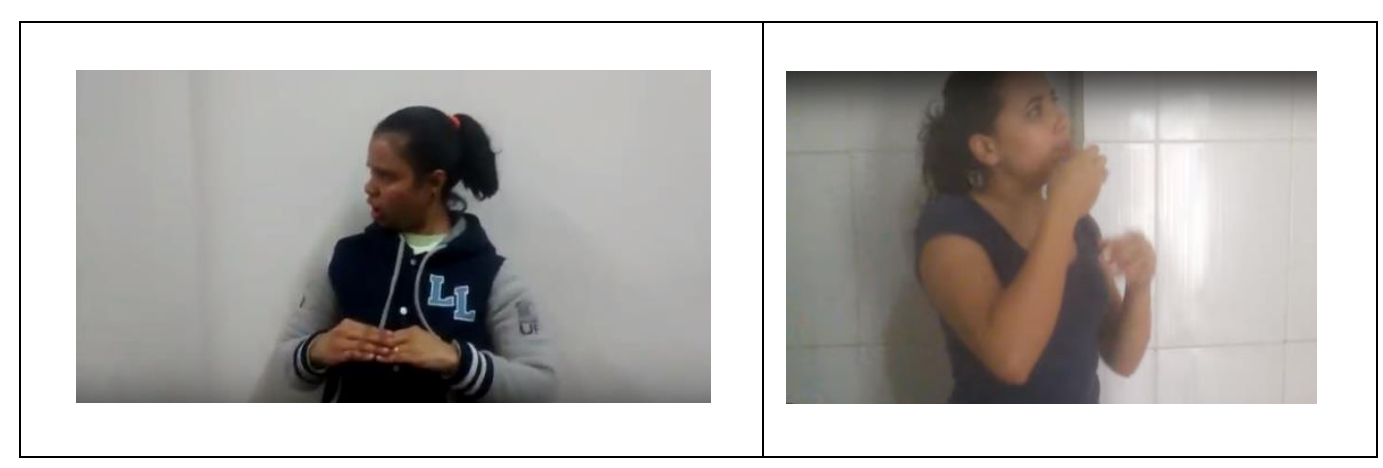

Revista Sinalizar, Goiânia, v. 2, n.2, p. 198 - 217, jul. / dez., 2017. 
Na Figura 10 temos os MDs interacionais produzidos por surdo e por ouvinte, respectivamente, para expressar a mesma sentença. Ambos os MDs são interacionais, mas o primeiro, o que foi produzido por um surdo, tem características mais gestuais do que o segundo, produzido pelo ouvinte.

Quando a bruxa teve a ideia de transformar a mulher bonita em uma sereia, ela expressou: “Ah! Tive uma idéia!” Nas ilustrações abaixo temos, na primeira linha, as realizações de MD produzidas por surdos (fotos a e b) e na segunda, por ouvintes (fotos c e d), respectivamente, para expressão da mesma sentença, expressa pela bruxa.

Figura 11 - MDs interacionais.

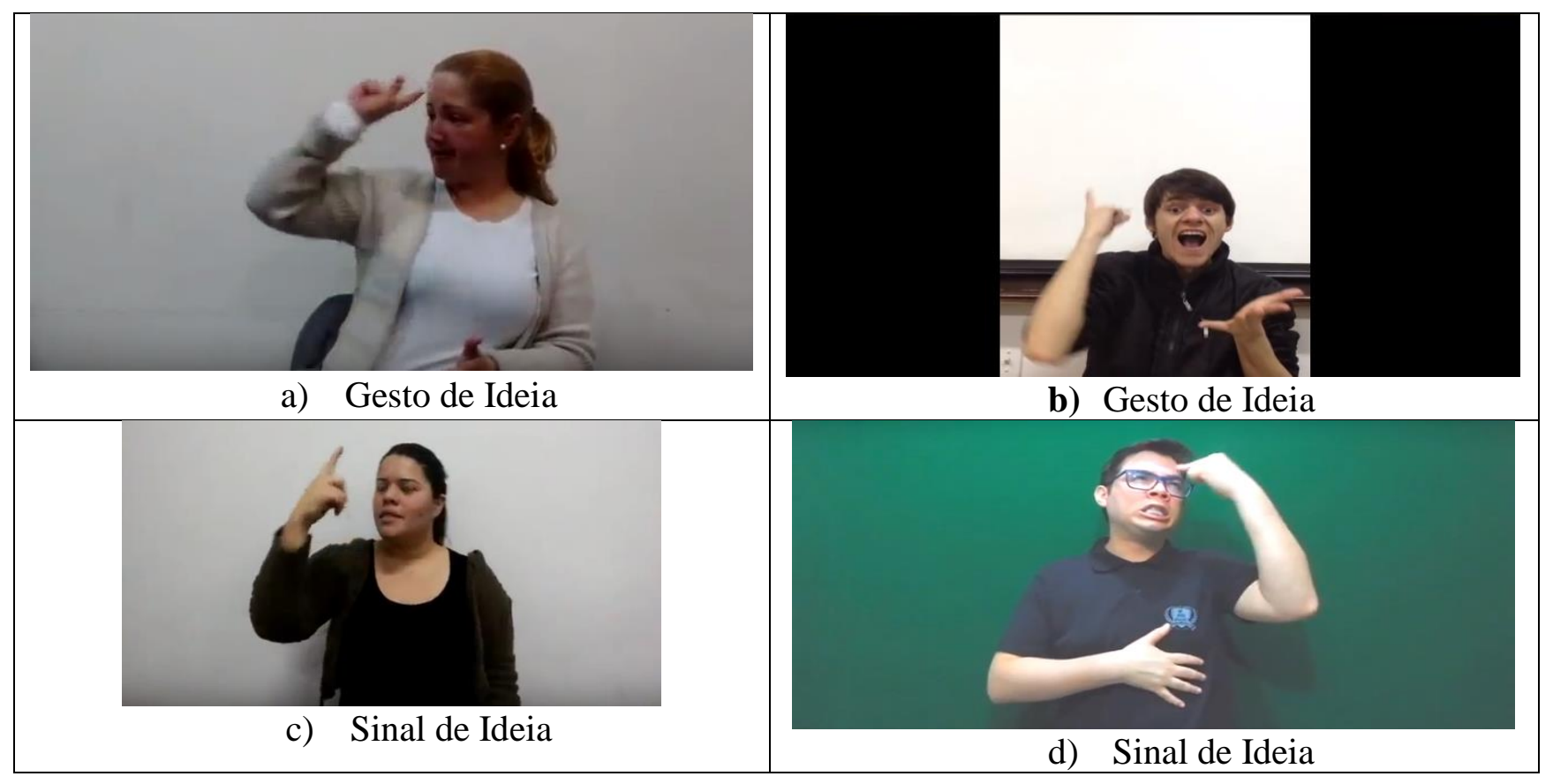

As quatro produções apresentam MDs com função interacional, mas os realizados por surdos (fotos a e b) têm características mais gestuais do que os produzidos pelos ouvintes (fotos $\mathrm{c}$ e d). Os surdos mantiveram mais detalhes da narrativa original (apresentada por Rimar R. Segala e Sueli Ramalho) do que os ouvintes.

\section{Discussão sobre os dados}

Segundo a Gramática Gerativa (CHOMSKY, 1965) há um componente biológico inato, que é responsável pela compreensão e pela produção da linguagem, denominado 
Gramática Universal (GU), que pode ser definida como um dispositivo acionado a partir do insumo ao qual a criança está exposta, que irá resultar na gramática de sua língua materna. Essa gramática é formada por regras, selecionadas pela criança de acordo com a sua língua nativa.

Nossos dados estão assentados sobre essas considerações de Chomsky (1965), pois, no caso dos graduandos surdos, que têm a Libras como primeira língua, além de toda a estrutura gramatical da língua já ter sido adquirida, eles apresentam maior capacidade de manipulação dos gestos de acompanhamento, ou seja, sentem-se confortáveis para sinalizar com mais refinamento, indo para além da possibilidade lexical, ao ponto de conseguir fazer inserções gestuais em sua produção discursiva.

No decorrer das atividades realizadas no curso de licenciatura em Letras Libras, investigou-se a produção de marcadores discursivos em Libras em graduandos surdos e ouvintes durante a sinalização da história "Três machados". Após a elaboração de um gráfico, com os dados recolhidos, foi possível perceber que houve preferência por parte dos surdos no emprego de MDs como gestos de acompanhamento, enquanto os ouvintes trouxeram muito mais MDs textuais e interacionais.

Gráfico 1 - Quantitativo de produção de MD por surdos e por ouvinte

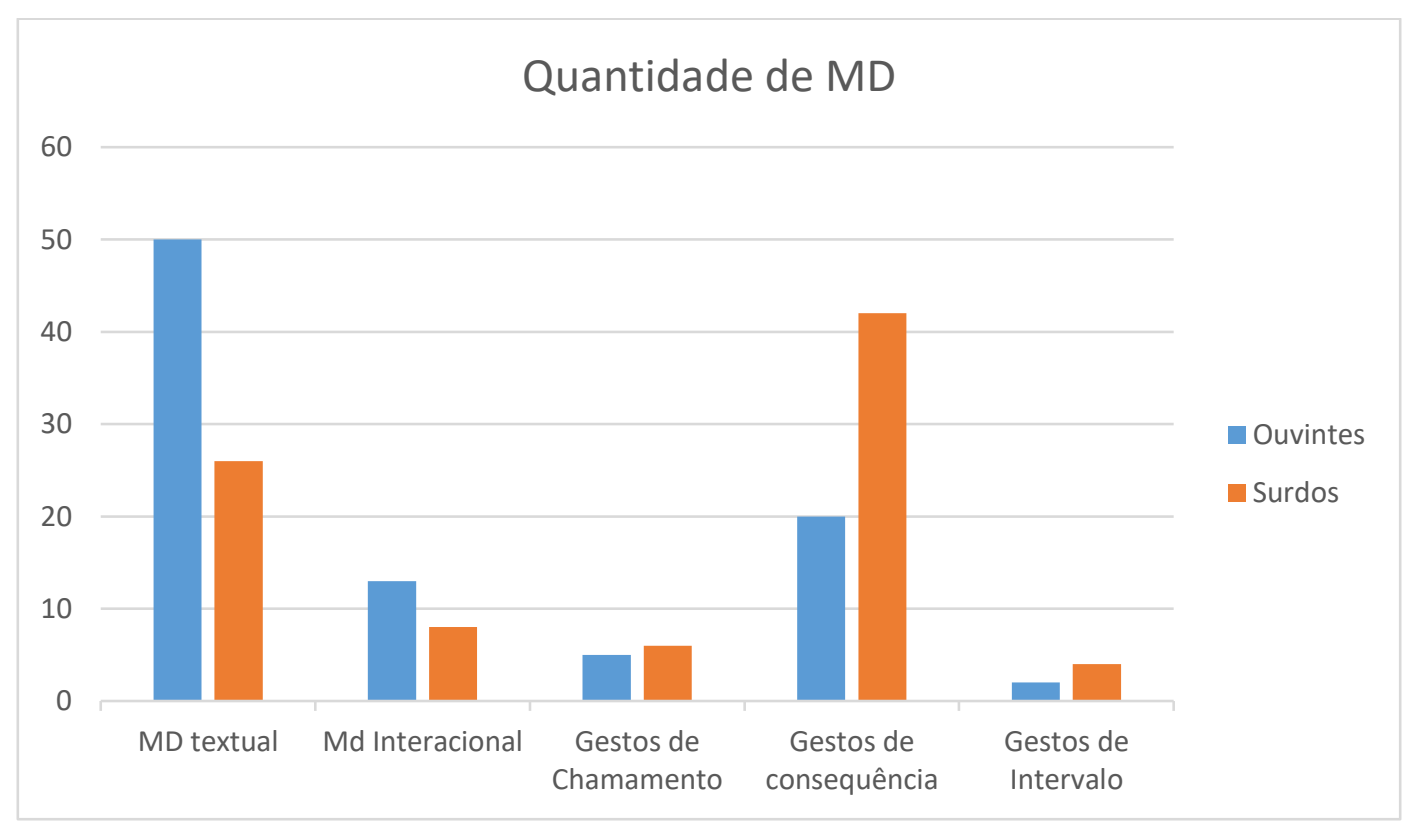

Revista Sinalizar, Goiânia, v. 2, n.2, p. 198 - 217, jul. / dez., 2017. 
O gráfico sugere uma questão: qual a razão da diferença de produção que ocorre entre surdos e ouvintes? Acompanhar o vídeo com o texto "Os três machados", apresentado por Rimar R. Segala, foi um estímulo para que os alunos surdos, em sua releitura do conto, usassem os MDs, tanto nas suas funções textuais como interacionais e gestuais. Observamos que, devido à estrutura internalizada de sua língua, apesar de os surdos saberem os sinais de IDEIA ou ESPERAR, preferiram utilizar um gesto de acompanhamento, como forma de expressividade linguística, dado o conforto para performance que eles têm.

Em relação à aquisição de segunda língua, White (2007) afirma que uma das questões que mobilizam os pesquisadores usuários da Gramática Universal, é sobre o estado inicial da aquisição da segunda língua. Quanto à idade de aquisição da Libras pelos graduandos ouvintes comparativamente aos surdos (que apesar da diferença de idade podem ser considerados adquirentes de primeira língua), organizamos a seguinte tabela:

Tabela 1: Faixa etária de aquisição da Libras pelos graduandos

\begin{tabular}{|c|c|c|c|}
\hline Categoria & $\mathbf{0 - 1 0}$ anos & 11-18 anos & Mais de 19 anos \\
\hline Ouvintes & 0 & 6 & 4 \\
\hline Surdos & 6 & 3 & 1 \\
\hline
\end{tabular}

Os dados apontam para o fato de que a aquisição de uma segunda língua tardiamente, após os 10 anos de idade, levou os ouvintes a apresentar maior tendência de uso de MDs com função textual (dada a interferência da sua L1) e isso se justifica na medida em que o acesso à estrutura latente da linguagem está parcialmente comprometido. É por isso que muitos dos adultos não chegam a adquirir a plenitude da língua, que pode se manifestar pelo uso dos gestos de acompanhamento. Observamos que enquanto os ouvintes estiverem presos ao sistema da língua portuguesa, sua sinalização deixará de lado aspectos importantes como os gestos de acompanhamento, cuja categoria exige maior precisão nas expressões faciais, corporais, direção do olhar e uso do espaço, entre outras.

No decorrer da pesquisa, notamos que os MDs do tipo "gestos de acompanhamento" têm um papel crucial na estruturação de discursos sinalizados e ainda que tal percepção necessite ser aprofundada, deixa uma pista acerca das constatações de Costello et al (2008) de que o grau de fluência de um sinalizador está intimamente ligado à alternância entre 
elementos linguísticos e elementos gestuais do discurso. Costello et al (2008) estudaram o discurso de surdos no país Basco e mostraram que os que tinham maior fluência tendiam a articular melhor os recursos oferecidos pela língua, fazendo uso de marcas corporais mais sutis. A partir dessas considerações, é possível supor que um maior nível de fluência favorece o uso mais frequente de MDs gestuais durante a sinalização de narrativas.

\section{Considerações finais}

Com a fundamentação teórica e a análise dos dados pudemos atingir os objetivos que havíamos proposto para este trabalho, ou seja, após observar as funções dos marcadores discursivos, presentes na sinalização de narrativas contadas por graduandos surdos e ouvintes, e avaliar semelhanças e diferenças dos marcadores discursivos em Libras produzidos em primeira e em segunda língua, determinar se haveria diferenças entre a produção discursiva de pessoas surdas que adquiriram essa língua como primeira língua e de ouvintes que adquiriram como segunda língua, quanto ao uso dos MDs.

Apropriamo-nos da conceituação de Risso et al (2008) para os marcadores discursivos, especialmente no que diz respeito às funções textuais, utilizando também suas reflexões sobre as funções interacionais deste mecanismo linguístico. Para argumentarmos a respeito do uso do espaço, nos apoiamos nos textos de Liddell (1995), sobre língua de sinais. Também utilizamos os pressupostos de McNeill (1992), para compreensão da gestualidade presente na narrativa sinalizada pelos graduandos, entendendo que os movimentos faciais e corporais aprimoram a mensagem em Libras.

Quanto aos MDs com função textual, destacamos os exemplos dos sinais de ENTÃO, AGORA e FIM, produzidos narrativa "Três machados", no vídeo de Rimar R. Segala, ressaltando o seu uso na narrativa como mecanismo de coesão, que estabelece algum tipo de relação semântica com os demais léxicos do enunciado. Quanto ao MD interacional, os exemplos de CERTO e COMO, devido ao uso do espaço sub-rogado em Libras, aparecem também em sinalização sem a presença do interlocutor.

Em relação à semelhança de produção entre surdos e ouvintes, no decorrer da sinalização da narrativa, identificamos produção de MDs com função textual, interacional e também nos gestos de acompanhamento do tipo chamamento, intervalo e consequência. Quanto às diferenças, os surdos são privilegiados quanto ao emprego de MDs, como os gestos 
de acompanhamento, atuando de forma diferente dos ouvintes, que trouxeram muito mais MDs textuais e interacionais, com performances diferenciadas, entre surdos e ouvintes. Questões sobre essas diferenças no uso dos MDs podem ser respondidas pela Teoria Gerativa. Como os graduandos surdos têm a Libras como sua primeira língua, eles naturalmente dominam a estrutura gramatical da língua, apresentando maior capacidade de manipulação dos gestos de acompanhamento, pois se sentem confortáveis para sinalizar ao ponto de conseguir fazer inserções gestuais ao seu discursivo. Já os graduandos ouvintes, por terem adquirido a Libras como segunda língua, possivelmente encontram-se em etapa intermediaria de desenvolvimento da interlíngua.

\begin{abstract}
The discourse markers of the Brazilian Sign Language are linguistic mechanisms used in the signalized expression and may have textual, interactional or discursive accompaniment function. Based mainly on Risso (1996) and McNeill (1992), we study this phenomenon using data from a narrative told by deaf graduates (for whom Libras is the first language) and hearing students (who use Libras as second language) of the degree course in Libras. Our objective was to describe the discourse markers present in the narrative and to analyze similarities and differences in relation to the production in the first and second languages. Our results point to a similar use between deaf and hearing students in what concerns textual and interactional discourse markers. However, when more refined resources, such as gestures, are used, the mechanism is more present in the narrative told by deaf people in their first language.
\end{abstract}

Keywords: Discursive markers. Libras. First and second language.

\title{
Resumen
}

Los marcadores discursivos de la Lengua Brasileña de Señales son mecanismos lingüísticos utilizados en la expresión señalizada y pueden tener función textual, interactiva o de acompañamiento discursivo. Fundamentados en Risso y McNeill, estudiamos este fenómeno, utilizando datos de una narrativa contada por alumnos sordos (que tienen la Libras como primera lengua) y alumnos oyentes (para los cuales Libras es una segunda lengua) del curso de grado Licenciatura en Letras Libras. El objetivo de este trabajo es describir los marcadores discursivos presentes en la narrativa y analizar semejanzas y diferencias sobre la producción en primera y segunda lengua. Los resultados apuntan para el análogo entre sordos y oyentes, en el caso de los marcadores discursivos textuales e interactivos, pero en el uso de recursos más refinados como gestos de acompañamiento, el mecanismo está más presente en la narrativa contada por los sordos.

Palabras-chave: Marcadores discursivos. Libras. Primera e segunda lengua. 


\section{Referências Bibliográficas}

CHOMSKY, N.. Aspects of the theory of syntax. Cambridge. MA: MIT Press, 1965.

COSTELLO, B.; FERNANDEZ, B.; LANDA, A.. The non-(existente) native signer: sign language research in a small deaf population. In: QUADROS, R.M (ed) Sign Languages: spinning and unraveling the past, present and future. Petrópolis : Editora Arara Azul. 2008. Disponível em: http://www.editora-arara-azul.com.br/ebooks/catalogo/7.pdf Acesso em 1 nov 2017.

FINAU, Rossana A.. Os sinais de tempo e aspecto na Libras. 2004. Tese (Doutorado em letras) - UFPR, Curitiba, 2004.

GESSER, A.. Libras? Que língua é essa? Crenças e preconceitos em torno da língua de sinais e da realidade surda. São Paulo: Parábola Editorial, 2009.

KENDON, Adam. Gesture: Visible Action as Utterance. UK: Cambridge University Press, 2004.

LIDDELL, S. K. Real, surrogateandtokenspace: gramatical consequences in ASL. Washington DC: GallaudetUniversity, 1995.

MARTELOTTA, Mário Eduardo et al. Manual de linguística. São Paulo: Contexto, 2011.

MCNEILL, David. Hand and Mind: what gestures reveal about thought. Chicago: Universityof Chicago Press.1992.

PENHAVEL, E. Sobre as funções dos Marcadores Discursivos. Estudos Lingüísticos XXXIV, p. 1296-1301, 2005.

QUADROS, R. M de; PIZZIO, A. L; REZENDE, P. L. F.. Língua Brasileira de Sinais II. Universidade Federal de Santa Catarina, 2008.

RISSO, M. S.; SILVA, G. M. O.; URBANO, H. "Marcadores discursivos: traços definidores". In: KOCH, I. G. V. (Org.). Interdisciplinar v. 6, n.6. p. 109-130 - Jul / Dez de 2008. Gramática do português falado. Campinas, SP: Editora da UNICAMP, 1996, p. 2161.

RISSO, M. S. et al. "Marcadores discursivos traços definidores". In: KOCH, I. G. V. (org.) Gramática do português falado. Vol. VI. Campinas: Ed. Da UNICAMP/FAPESP, 1996.

WHITE, L. Linguistic theory, universal grammar, and second language acquisition. In: VAN PATTEN, B. e WILLIAMS, J. Theories in second language e acquisition: an introduction. Hillsdale, NJ: Erlbaum Associates, 2007.

KENDON, Adam. Gesture: Visible Action as Ulterance. Cambrige: Cambridge University Press, 2004. 


\begin{abstract}
Notas
${ }^{1}$ Sobre essa consideração, consultar: http://www.signwriting.org/brazil/

${ }^{2}$ Alguns autores tratam da corporalidade em analogia com a oralidade.

${ }^{3}$ Texto em português da narrativa surda "Os três machados", de Rimar Segala e Sueli Ramalho:
\end{abstract}

Agora eu vou contar uma história muito bonita, chamada "Os três machados". Havia uma mulher muito bonita, com longos cabelos ondulados, que era admirada por todos do reino por causa da sua beleza. Havia também uma bruxa que sentia muita raiva por causa da beleza da mulher e a odiava. Por conta disso, teve a idéia de fazer uma poção mágica, um feitiço, e jogou contra a mulher, que se transformou em uma sereia e foi para a lagoa. A bruxa disse que se ela só encontrasse pessoas falsas, ficaria como sereia para sempre, mas se encontrasse um homem honesto, que falasse a verdade, ela voltaria a ter sua forma de mulher. A sereia, desanimada, foi ao fundo da lagoa e lá ficou por muitos anos. Até que um dia, apareceu um homem, inocente e humilde, que trabalhava cortando árvores, um lenhador. Ele estava andando com seu machado por aquele lugar e avistou uma árvore. Começou a bater com o machado contra a árvore até que ela caiu. Muito satisfeito, o lenhador continuou cortando as árvores próximas, até que seu machado se desprendeu do cabo e caiu na lagoa. Como o lenhador não sabia nadar ficou inconformado, pensando no que iria fazer. Nessa hora, a sereia apareceu na beira da lagoa, perguntando o que tinha acontecido. O lenhador assustou-se e lhe pediu para pegar o machado. A sereia foi ao fundo da lagoa e encontrou um machado que não era o que ele havia perdido. Era um machado de ouro reluzente. A sereia entregou esse machado ao lenhador, que quando o viu, explicou que aquele não era o seu machado, mesmo diante da insistência da sereia, que falou sobre as qualidades daquele machado. Então ela foi ao fundo da lagoa e encontrou o machado dele, que era velho, enferrujado, carcomido, mas foi esse que o lenhador aceitou receber. Assim que recebeu o machado, o lenhador se assustou ao ver a sereia se transformar, voltar à forma humana de mulher.

4 Optamos por uma forma narrativa, pois esse gênero minimiza a interferência de outros elementos como a troca de turnos, característicos da interação, e também por entendemos que os marcadores servem para estabelecer coesão entre as informações não somente durante a conversão mais em diversas manifestações da sinalização como o contar uma história.

${ }^{5}$ Rimar Romano Segala é fundador da Cia. Arte e Silêncio. As imagens apresentadas neste trabalho são públicas, disponíveis no Youtube: https://www.youtube.com/watch?v=dj3MJnJjvsY

6 A iconicidade na Libras ocorre de forma diferente, em relação às línguas orais. Por ser uma língua de modalidade visuoespacial, a iconicidade está presente em grande parte dos sinais da Libras, pois a relação entre a "forma" e o "sentido" é mais visível. De acordo com Martelotta (2011, p. 73), iconicidade se refere às características em comum entre o ícone e o objeto que representa.

Revista Sinalizar, Goiânia, v. 2, n.2, p. 198 - 217, jul. / dez., 2017. 